Cell Research (1999), 9, 37-49

\title{
Growth induction of hepatic stimulator substance in he-patocytes through its regulation on EGF re- ceptors
}

\author{
AN Wei*, Xiao Jun LIU, Tian Guang LEI, Jie DAI, \\ Guo Guang DU \\ Department of Cell Biology, Capital University of Medical \\ Sciences, Beijing 100054, China
}

\begin{abstract}
The cytosolic liver-specific growth factor-hepatic stimulator substance (HSS) has been shown to be able to amplify the rat hepatocyte proliferation responded to EGF. In order to get more insight into the mechanism, the regulatory effect of HSS on EGF-receptor (EGF-R) and the receptor phosphorylation at molecular level was studied. HSS partially purified from weanling rat liver was given to cultured hepatocytes and its influence on EGF-R specific binding and internalization as well as mRNA expression were investigated. The results showed that preincubation of hepatocytes with HSS could lead to an increase in $\left.{ }^{[125} \mathrm{I}\right]-\mathrm{EGF}$ binding to its receptors and inhibit EGFinduced receptor down-regulation. Furthermore, the over-expression of EGF-R mRNA stimulated by HSS was seen during 2-12 $\mathrm{h}$ after the incubation. Additionally, it was demonstrated with human hepatoma SMMC-7721 cells in Western blot that the EGF-R expression and the receptorautophosphorylation were increased with dose/time-dependency after HSS treatment . These results strongly suggest that the mechanism of HSS action on hepatocyte growth might be related to its modulation on EGF-R and receptor-mediated signaling transduction .
\end{abstract}

Key words: EGF receptor, hepatic stimulator substance, hepatocyte proliferation. 
Regulation of HSS on EGF-receptor

\section{INTRODUCTION}

Hepatic stimulator substance (HSS), which was initially found in the cytosol of weanling rat liver[1], has been considered as one of new liver-derived growth factors, as more implications of its stimulatory effect on the hepatocyte proliferation and liver regeneration have been clearly obtained. HSS, upon acting on hepatocytes and through a so-far unknown mechanism, stimulates the cell DNA synthesis[2],[3], promotes the cell proliferation and even more alleviates liver injuries induced by $\mathrm{CCl}_{4}$ and $\mathrm{D}$-galactosamine in mice[4]. Although the importance of HSS in the regulation of liver regeneration is well recognized, the mechanism by which HSS acts on hepatocytes remain still unclear.

It has been recently reported that HSS itself can hardly affect the growth of the resting liver cells such as primary cultured hepatocytes, but makes them potential to be stimulated significantly by EGF and other hepatic mitogenic factors[5]. In this sense, HSS might function as an incomplete mitogen to promote liver regeneration. However, there are still some questions concerning the mechanism of HSS action left to be answered, for example, by what way HSS acts on hepatocytes, how it regulates the hepatocyte proliferation, or even, whether it interacts with other known growth factors such as EGF, and if so, in which signal transduction pathway it might be involved. In this study, we investigated regulation of HSS on EGF-receptor at the molecular level, aiming at the further understanding of the mechanism of HSS action.

\section{MATERIALS AND METHODS}

\section{Reagents}

cDNA probe, pE7 and GAPDH, which encoded EGF receptor and glyceraldehyde-3-phosphate dehydrogenase respectively were obtained from American Type Culture Collection (ATCC, Rockville, USA). All the cell-culture mediums and relevant products were purchased from GIBCO/ BRL (Gaithersburg, USA). mRNA purification kit and random primer labeling kit were from Promega (Madison, USA). Insulin, EGF (culture grade), monoclonal anti-EGF-receptor antibody (internal domain, clone F4), monoclonal anti-phosphotyrosine antibody and Western blot assay kit were purchased from Boehringer Mannheim (Mannheim, Germany). [ $\left.{ }^{125} \mathrm{I}\right]-\mathrm{EGF}$ and [ $\alpha$ ${ }^{32} \mathrm{P}$ ]-dCTP were produced by Amersham International (Buckinhamshire, UK). The other chemical reagents used in the experiments were analytical grade and commercially available from different companies.

\section{Hepatocyte isolation and culture}

Rat hepatocytes were isolated by recirculating liver perfusion in situ as previously described [6]. The hepatocytes with viability of $90 \%$ as judged by trypan blue exclusion were cultured in DMEM supplemented with $10 \%$ fetal calf serum at $5 \% \mathrm{CO}_{2}$ at $37^{\circ} \mathrm{C} . \mathrm{MH} 1 \mathrm{C} 1$ cells (rat hepatoma) were grown in F-10 medium supplemented with $7.5 \%$ horse serum plus $2.5 \%$ fetal calf serum. SMMC-7721 cells (human hepatoma) were cultivated in DMEM plus $10 \%$ fetal calf serum. The culture condition was $95 \%$ humidified atmosphere with $5 \% \mathrm{CO}_{2}$.

\section{HSS preparation and purification}

Male weanling Sprague-Dawley rats, weighing 60-80 g, were fed under the schedule-lighted 
An W et al.

condition with 7:00 a.m. to 7:00 p.m. light and 7:00 p.m. to 7:00 a.m. dark for a week. The animals were killed by cervical dislocation and the livers were removed immediately. HSS was extracted according to the method described by LaBrecque[7] and Fleig[3]. Briefly, the livers were flushed with Dulbecco'b phosphate-buffered saline (PBS, $\mathrm{pH} 7.4$ ) via the portal vein, weighed and homogenated to $35 \%$ in $\mathrm{PBS}(\mathrm{w} / \mathrm{v})$. The homogenate was heated at $95{ }^{\circ} \mathrm{C}$ for $30 \mathrm{~min}$. After centrifugation at $27,000 \mathrm{~g}$ for $20 \mathrm{~min}$, the supernatant was immediately recentrifuged at 100,000 $\mathrm{g}$ for $1 \mathrm{~h}$. The supernatant was referred as crude preparation of liver cytosol and subjected to partial purification using gel filtration chromatography (Sephadex G-75 superfine, Pharmacia, Uppsala, Sweden). Four peaks were eluted as determined by protein concentration after the gel filtration. The activity analysis of these peak proteins was followed by the non-radioactive method as described previously[8]. The most active portion of HSS (the elution volume 260-270 ml) was pooled, lyophilized and stored at $-20{ }^{\circ} \mathrm{C}$ until use. This portion of HSS was fractionated with $15 \%$ SDS-polyacrylamide gel electrophoresis (SDS-PAGE) and detected with silver stain.

\section{Binding assay of ${ }^{125}$ I-EGF to receptor}

The $\left[{ }^{125} \mathrm{I}\right]$-EGF specific binding to cell surface EGF-receptors and intracellular internalization were measured at $37^{\circ} \mathrm{C}$ as previously described[9]. For determination of time dependency of EGF binding to the receptors, the serum-free cultured hepatocytes were incubated with $10 \mathrm{nM}\left[{ }^{125} \mathrm{I}\right]$ EGF $(50,000 \mathrm{cpm})$ against $10 \mathrm{pM}$ unlabeled EGF for $30,60,90,120$ and $240 \mathrm{~min}$. After the incubation, the cells were washed three times with cold PBS ( $\mathrm{pH} 7.4)$ to eliminate free radioactive $\left[{ }^{125} \mathrm{I}\right]-\mathrm{EGF}$. The measurement of radioactivity of these cells represented total $\left[{ }^{125} \mathrm{I}\right]$-EGF binding to its receptor. In parallel, the radioactively labeled hepatocytes, upon the above mentioned times, were treated with $10 \%$ trichloroacetic acid (TCA) which enabled to separate the intact [125I]-EGF bound on the cell surface from the degraded $\left[{ }^{125} \mathrm{I}\right]-\mathrm{EGF}$. The remaining radioactivities in the cells indicated the $\left.{ }^{[125} \mathrm{I}\right]-\mathrm{EGF}$ specific binding to the hepatocytes. Afterward, the cells were washed 5 times thoroughly with PBS and subjected to membrane preparation[10]. The amount of EGFreceptor internalization could be calculated from the radioactive surplus between the cellular specific binding and membrane binding of $\left[{ }^{125} \mathrm{I}\right]-\mathrm{EGF}$.

\section{RNA preparation and Northern blot}

The hepatocytes were incubated with EGF $(10 \mathrm{ng} / \mathrm{ml})$, HSS $(50 \mu \mathrm{g} / \mathrm{ml})$ and EGF $(10 \mathrm{ng} / \mathrm{ml}) / \mathrm{HSS}$ $(50 \mu \mathrm{g} / \mathrm{ml})$ for $2,6,12$ and $24 \mathrm{~h}$, respectively. Total cellular RNA was extracted by the method of Chomczyniski and Sacchi[11] and subjected to purification into mRNA with Promega PolyATract mRNA isolation system (Madison, USA). $5 \mu \mathrm{g}$ mRNA, denatured with $50 \%$ deioned formamide and 2.5M formaldehyde, was electrophoresed in 1.2\% MOPS/formaldehyde-containing agarose and then was blotted onto nitrocellulose membrane. The membrane was hybridized with $100 \mathrm{ng}$ cDNA of $\left[{ }^{32} \mathrm{P}\right]$ labeled-Cla I fragment of $\mathrm{pE} 7$ (coding for EGF receptor) at $42^{\circ} \mathrm{C}$ for $16 \mathrm{~h}$. After being washed thoroughly, the membrane was subjected to autoradiography on X-ray film. To verify the uniformity of mRNA loading during Northern blot, a rat glyceraldehyde phosphate dehydrogenase $(\mathrm{GAPDH}) \mathrm{cDNA}$ probe was used for normalization. Both probes were labeled with $\left[\alpha-{ }^{32} \mathrm{P}\right]-$ dCTP using random primer labeling kit to specific activity of $2 \times 10^{8} \mathrm{cpm} / \beta \mathrm{g}$ DNA. The band signals on the exposed film were quantified by laser densitometer.

\section{Cell lysis and Western blot}

In order to study the possible role of HSS on EGF-receptor and receptor-mediated signal transduction, SMMC-7721 cells were used to investigate the expression level of the receptor and receptor phosphorylation. The hepatoma cells were grown in serum-free DMEM medium for 24 $\mathrm{h}$, and then the EGF, HSS and EGF/HSS (same dosages as described above) were added into the medium for incubation of $6,12,24,36$ and $48 \mathrm{~h}$. Upon these schedule-points, the cells were harvested, washed with PBS (pH 7.4) and lysed with ice-cold lysis buffer (50 nM Tris-HCl, pH 7. 2; $150 \mathrm{mM} \mathrm{NaCl} ; 1 \mathrm{mM}$ EDTA; $10 \%$ Triton X-100; 0.1\% SDS; $1 \mathrm{mM}$ PMSF and $0.1 \%$ aprotinin). 


\section{Regulation of HSS on EGF-receptor}

The lysate was clarified by centrifugation at $100,000 \mathrm{~g}$ at $4^{\circ} \mathrm{C}$ for $30 \mathrm{~min} .100 \mu \mathrm{g}$ of the proteins from the supernatant were fractionated by 7.5\% SDS-PAGE[12] and electrotransferred onto the nitrocellulose membrane. After transferring, the blots were incubated consecutively with antiEGF-receptor monoclonal antibodies (dilution 1:500) and horseradish peroxidase-conjugated anti-mouse/rabbit IgG. The blots were developed with chemiluminescence detection reagents (Boehrigner Mannheim, Mannheim, Germany). The densities of the immunoblots were scanned with laser densitometer. For the detection of EGF-receptor phosphorylation, the procedures of Western blot were same as above-described, but different in time-schedules for HSS incubation (see results). In addition, monoclonal antibody for detection of autophosphorylation was antiphosphotyrosine antibody (mouse IgG). NaF was supplemented during preparation of cell lysate to prevent dephosphorylation induced by protein phosphatase.

\section{Statistical analysis}

The data shown in the experiment were the means \pm SD of three cell-preparations. Statistical significance was estimated with Student's test. $\mathrm{P}$ values $<0.05$ were considered significant.

\section{RESULTS}

\section{Activity assay of HSS}

After the heat-denaturation and ultracentrifugation of weanling rat liver homogenate, the crude extract was fractionated by gel-filtration chromatography. Four peaks in the elution were detected with bicinchoninic acid (BCA) protein assay[13]. The activity assay of these peaks indicated that only the rising position of the peak 4 was able to proliferate MH1C1 cells[8, 14] (Fig 1). SDS-PAGE of this portion demonstrated clearly visual band corresponding to $15,000 \mathrm{Da}$ after silver stain (data not shown). Accordingly, the active portions of HSS were pooled, lyophilized and ultilized in the following experiments.

Fig 1. Elution profiles of HSS and activity assay. The liver cytosol homogenate was purified by ultracentrifuge and subjected to size exclusion chromatography. The elution profiles were pooled and their activities were analyzed with non-isotope method as described in Materials and Methods. The dashed line (-) represented elution of gelfiltration chromatography and dot line ( $\cdots$ ) indicated activities of the corresponding fractions.

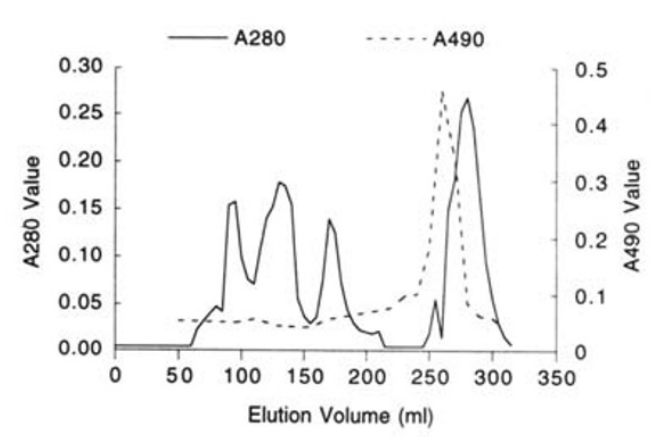

\section{Influences of EGF and HSS on hepatocyte EGF receptor metabolism}

The association of [ $\left.{ }^{125} \mathrm{I}\right]$-EGF with hepatocytes was shown in Fig 2 . The binding of EGF to the receptor rose sharply within $60 \mathrm{~min}$. After a plateau between 60 to $90 \mathrm{~min}$, the binding capacity declined gradually. The specific bindings were mainly contributed by surface-bound and internalized receptors. After $5 \mathrm{~min}$ of incubation, the receptors com- 
menced to internalize. Upon $10 \mathrm{~min}$, it seemed that the numbers of the internalized receptors exceeded those of the surface-bound, indicating that the internalization of the ligandreceptor took place rapidly after EGF binding to the hepatocyte surface receptors.

Fig 2. Time-dependency of EGF binding, internalization and degradation in cultured hepatocytes. The serum-free cultured hepatocytes were incubated with $10 \mathrm{nM}\left[{ }^{125} \mathrm{I}\right]$-EGF $(50,000 \mathrm{cpm})$ for various times and washed with PBS (pH 7. 4) to eliminate unbound $\left[{ }^{125} \mathrm{I}\right]-\mathrm{EGF}$. Subsequently, the radioactivities were measured with $\gamma$-counter, which represented total EGF specific binding to the receptors. The surface-bound [ $\left.{ }^{125} \mathrm{I}\right]-$ EGF was separated from the degraded ones by $10 \%$ TCA treat ment and measurement of the cellular radioactivities was carried out again. The remaining of $\left.{ }^{[25} \mathrm{I}\right]$-EGF was quantified as the intact cellular-bound both on the sur-

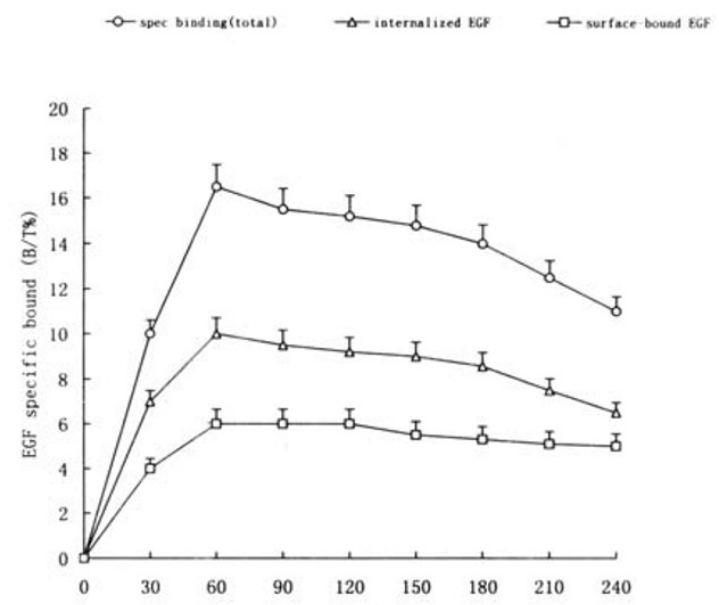
face and inside. The cell membrane was prepared and the radioactively assayed. The internalization could be deduced from value differences between the cellular and surface-bound [125I]-EGF. (- 0 - tatal spec binding;- $\Delta$ - internalized EGF; - $\square$ - surface bound EGF)

In order to understand the binding effects of HSS and EGF on the EGF-receptor, the hepatocytes were maintained in the medium with or without EGF and HSS for 4-48 $\mathrm{h}$ and subsequently incubated with $10 \mathrm{nM}$ of [ $\left.{ }^{125} \mathrm{I}\right]$-EGF against $1 \mathrm{pM}$ of unlabeled EGF for binding assay. Fig 3 showed the analysis of specific EGF-binding in pattern of Scatchard-plots. The EGF-binding capacity in the hepatocytes was inversely proportional to the numbers of free-receptors. The specific binding consisted of two parts of receptors, one part was on the cell surface and another within the cells. The more the receptors were occupied, the less the specific bindings were produced. Preincubation with $10 \mathrm{nM}$ EGF led to ca. $40 \%$ reduction $(\mathrm{P}<0.01)$ of the specific binding. Contrary to EGF, preincubation with $50 \mu$ $\mathrm{g} / \mathrm{ml}$ of HSS resulted in an increase in EGF specific binding to the receptors by ca. $25 \%$ ( $\mathrm{P}$ $<0.05$ ). Surprisingly, the down-regulation of EGF receptors by different concentrations of EGF (reduction of ca. 40\%) could be overcome by the addition of HSS (Fig 3a). The parallel movement of the binding curve along with Y-axis indicated that the reduction of the specific binding was not resulted from the decrease in receptor affnities, but from the decrease in receptor numbers (Fig 3a). The influences of HSS and EGF on the receptor specific bindings were shown in Fig 3b. In Fig 3b, it seemed that HSS itself, except in the initial part of scatchard plot, did not result in the increase in EGF binding to its receptors, nor overturn the receptor down-regulation, suggesting that the regulation of HSS on 


\section{Regulation of HSS on EGF-receptor}

EGF receptor was probably involved in their intracellular metabolism such as internalization or even signal transduction. Fig $3 c$ clearly demonstrated that the internalization of EGF-receptors was indeed regulated so significantly by HSS that the curve alignments in the Fig $3 \mathrm{c}$ were similar to those in Fig 3a. Therefore, it seems likely to conclude that the regulation of HSS on EGF-receptors is associated, in great part, with EGF-intracellular metabolism, or in other words, with the post-receptor steps.

\section{EGF-receptor $m R N A$ expression}

As indicated in Fig 3, HSS could reverse the EGF down-regulation of specific binding to EGF-receptor. The turnover effect of HSS indicated that HSS probably stimulated the synthesis of EGF-receptor and expression of the receptors.

To characterize the possibility of HSS-promoted synthesis of EGF-receptor at molecular level, the EGF-R mRNA expression in hepatocytes was detected after stimulation with HSS and EGF. As shown in Fig 4 (adopted from ref.[15]), preincubation of the hepatocytes with either $10 \mathrm{ng} / \mathrm{ml}$ of EGF or $50 \mu \mathrm{g} / \mathrm{ml}$ of HSS stimulated the expression of EGFreceptor mRNA. The EGF-receptor mRNA was composed by three transcripts, 2.4, 5.6 and $10.0 \mathrm{~kb}$ [15], of which, only 5.6 and $10.0 \mathrm{~kb}$ transcripts responded to HSS. The mRNA expression stimulated by EGF plus HSS was increased obviously from 2 to $12 \mathrm{~h}$ after the incubation (Tab 1, adopted from ref.[15]). The stimulatory effect of HSS appeared to be more or less stronger than EGF at $6 \mathrm{~h}$, meanwhile, the actions of HSS and EGF seemed to be synergized both at 2 and $24 \mathrm{~h}$. It might be considered that the up-regulation of HSS on EGF-receptor mRNA expression provided the hepatocytes a great deal of newly synthesized EGF-receptors, which in theory, could be rebound EGF consequentially specific binding.

Tab 1. Densitometry of Northern blot of EGF-R

\begin{tabular}{lcccc}
\hline & \multicolumn{4}{c}{ Time/hours } \\
Groups & 2 & 6 & 12 & 24 \\
\hline Control & 100 & 100 & 100 & 100 \\
EGF & 198 & 180 & 221 & 166 \\
HSS & 178 & 220 & 188 & 152 \\
HSS+EGF & 246 & 170 & 194 & 198 \\
\hline
\end{tabular}

The data in the table represent the densitometic analysis of N6rthern blot. The control values at different times were considered as $100 \%$.

Fig 3. Regulation of EGF-binding, internalization and degradation by HSS. The upper: plot of total specific binding; the middle: plot of surface binding; the bottom: plot of internalization. The binding assay was performed as described in Materials and Methods as well as in Fig 2. The data were mean $\pm \mathrm{SD}$ of three cell-preparations. 
An W et al.
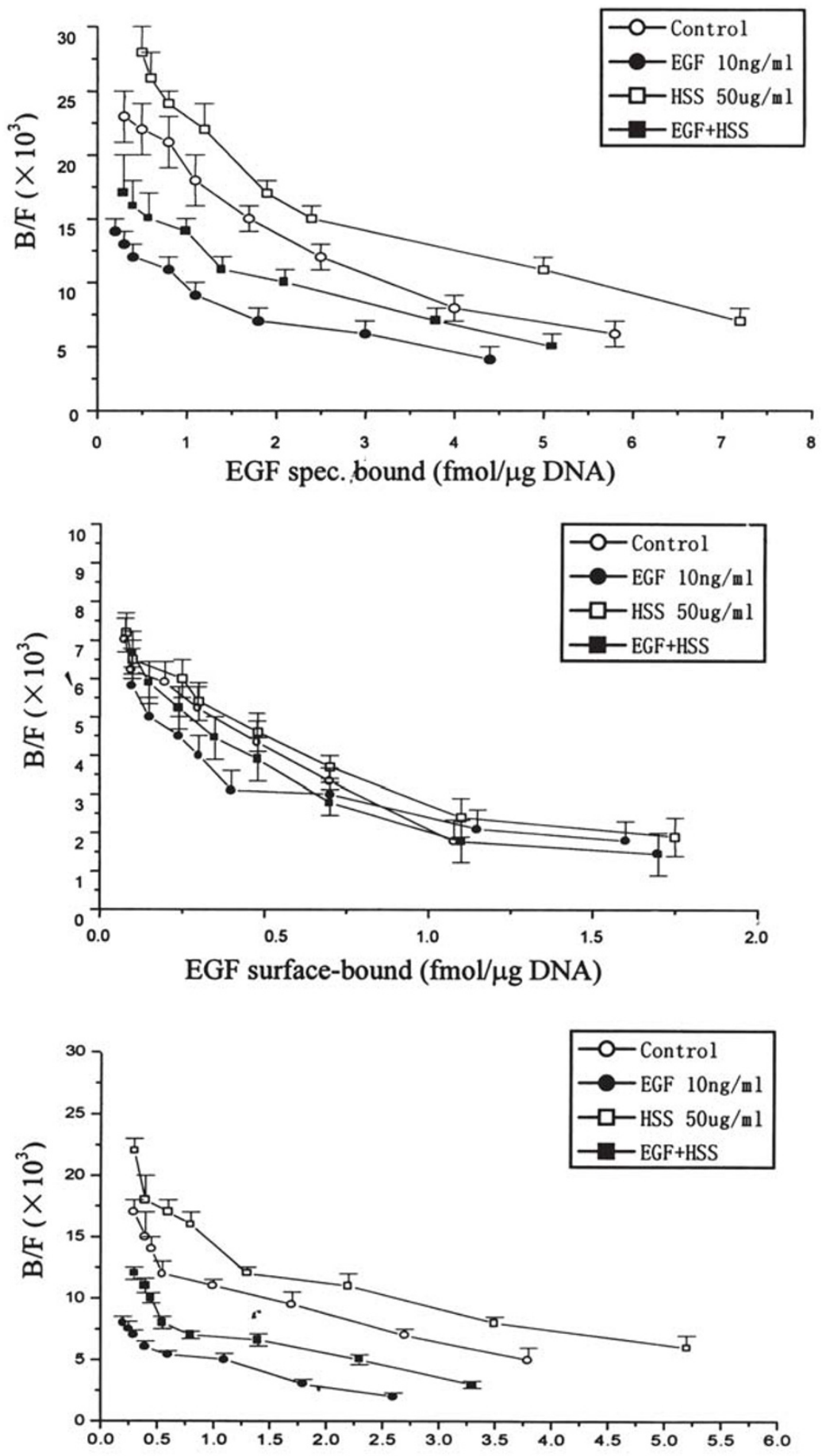

EGF internalized (fmol/ $\mu \mathrm{g}$ DNA) 
Regulation of HSS on EGF-receptor

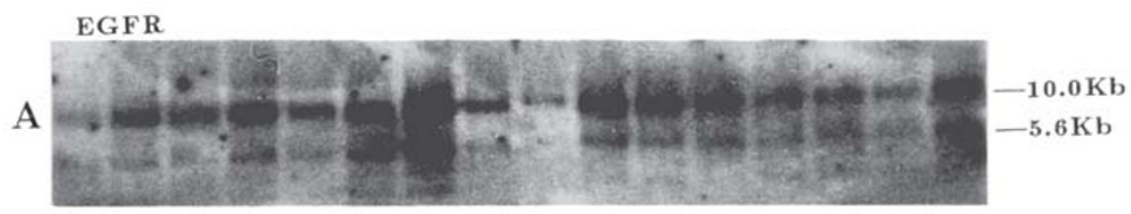

GAPDH

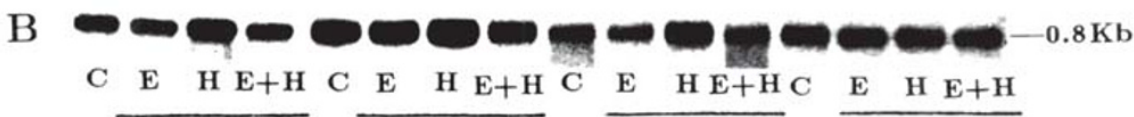

Fig 4. Regulation of HSS on EGF-receptor mRNA expression. Total cellular RNA was prepared and purified into mRNA. After transferring to nitrocellulose membrane, mRNA was blotted with Pst I fragment of $\mathrm{pE} 7$ (entire cDNA insert of EGF receptor). The upper panel indicated Northern blot of EGF-receptor mRNA and the lower was the blot of internal standard of GAPDH as control.

\section{Western blot analysis of EGF-receptor and receptor autophosphorylation}

To investigate the consequence of HSS up-regulation on EGF-receptor mRNA expression, we subsequently investigated in more detail whether the HSS stimulated expression of EGF-receptor as well as the receptor phosphorylation following HSS stimulation. SMMC-7721 cells were grown confluently in serum-free DMEM medium and exposed to either $50 \mu \mathrm{g} / \mathrm{ml}$ of HSS, $10 \mathrm{ng} / \mathrm{ml}$ of EGF or HSS plus EGF $(50 \mu \mathrm{g} / \mathrm{ml}+10 \mathrm{ng} / \mathrm{ml})$ at $37 \mathrm{oC}$ for varying periods of time. The cells were lysed and total proteins were extracted as described in Materials and Methods. As shown in Fig 5, the HSS-induced over-expression of EGF-receptor commenced at $12 \mathrm{~h}$ after the incubation and was maximized at $24 \mathrm{~h}$, and then decreased slightly till the control level at $48 \mathrm{~h}$. An over-expression of EGFreceptor provoked by EGF appeared earlier as compared with HSS, presenting the peakvalue at $6 \mathrm{~h}$. Similarly, synergism of HSS and EGF on EGF-receptor expression was also observed when the SMMC-7721 cells were treated with both HSS and EGF simultaneously. The effect of HSS appeared to be dose-dependenty (Fig 6).

In addition to the receptor expression, we observed the effect of HSS on EGF-receptor autophosphorylation as well. The phosphorylation of tyrosine residue-containing receptor has been considered as a typical marker of receptor activation[16,17]. The result shown in Fig 7A displayed that the tyrosine phosphorylation of the EGF receptors was enhanced from 0.5 to $15 \mathrm{~min}$ after HSS stimulation. The incubation of the cells with HSS longer than 60 min did not influence EGF-receptor phosphorylation any more, suggest- 
An W et al.

ing the HSS regulation on EGF-receptor took place only in the initial phase of hepatic proliferation[18]. The enhancement of EGF-receptor phosphorylation generated by HSS revealed also a dose-dependent manner and the maximum response of the cells to HSS dosage was achieved by $100 \mu \mathrm{g} / \mathrm{ml}$ (Fig 7B).

A

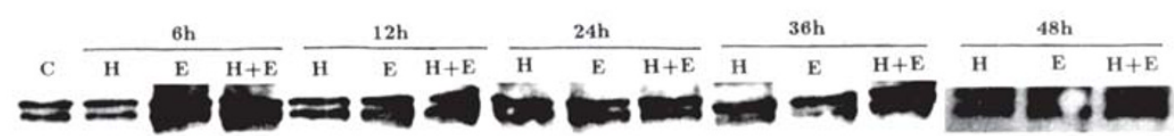

B

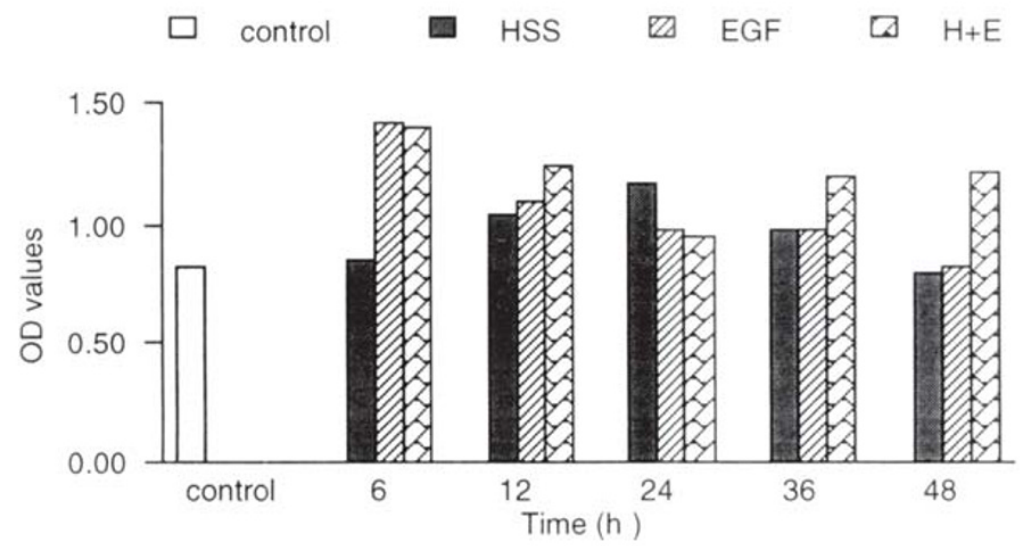

Fig 5. Effect of HSS and EGF on EGF-receptor. SMMC-7721 hepatoma cells were treated with EGF and HSS as described in Material and Methods. The cells were harvested and lysed with lysis buffer. The amounts of cell proteins $(100 \mu \mathrm{g})$ were analyzed using Western blot for EGF receptor expression. Panel A indicated the immunoblots and panel B represented the scanned densities of the upper blots.

Fig 6. Dose-related expression of EGF-receptor by HSS. SMMC-7721 cells were incubated with 5 different concentrations of HSS and preparation of cellular proteins at those time points was performed as indicated in Materials and Methods. $100 \mu \mathrm{g}$ proteins were separated by $7.5 \%$ SDS-PAGE and blotted to anti-EGF receptor antibodies. The upper was Western blot analysis of the cell preparation and the lower referred to the densities of the Western blots.

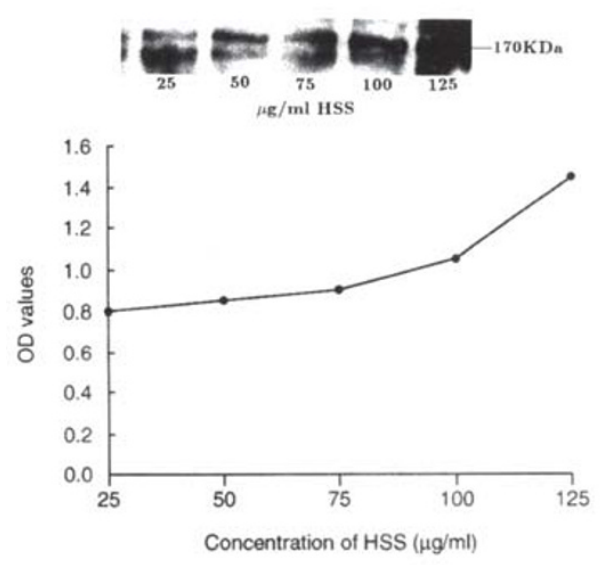



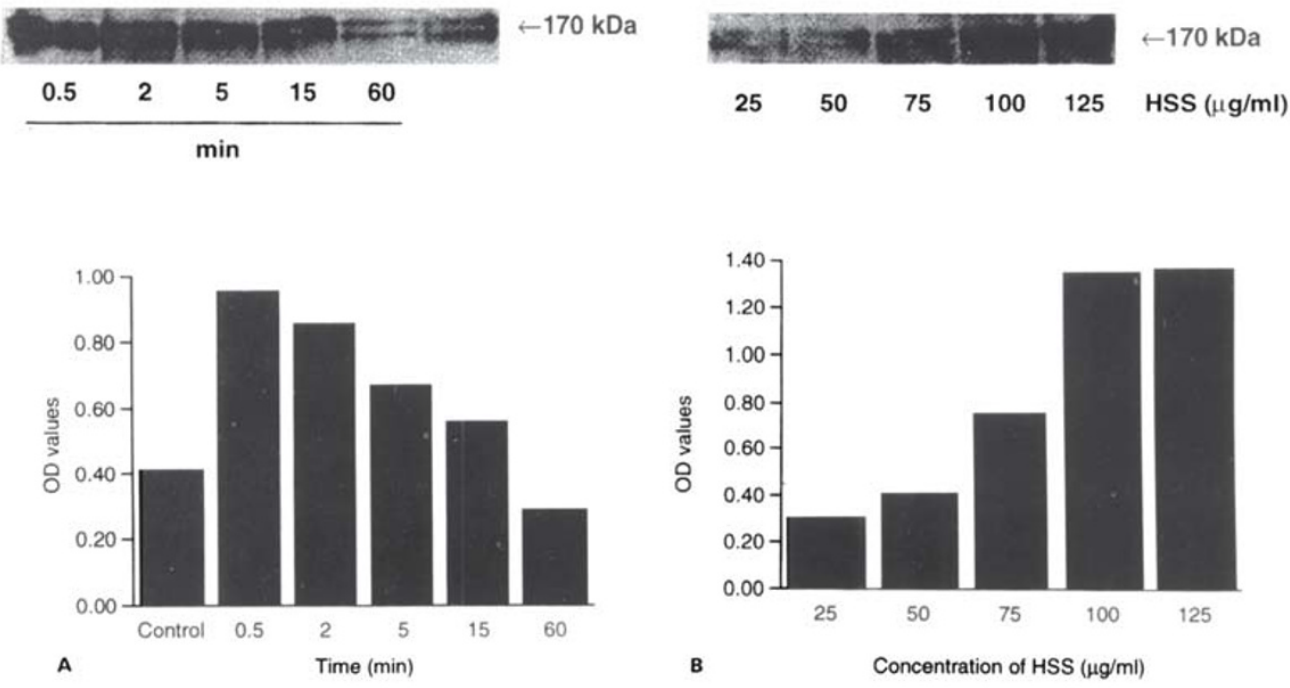

Fig 7. Time/dose-dependency of EGF-receptor phosphorylation. The hepatocytes were incu bated with HSS for time from 0.5 to $60 \mathrm{~min}$. The cells were then harvested and proteins of the cells were prepared. After electrophoresis, phosphorylation of EGF receptor was detected with Western blot (A). The significant dose-dependency of EGF-receptor phosphorylation was seen in HSS from $25-100 \mu \mathrm{g} / \mathrm{ml}$ (B).

\section{DISCUSION}

Hepatic stimulator substance came first into light in 1975 with the study of liver regeneration. After a subtotal resection of adult rat liver, the remnant liver commenced to proliferate dramatically if the cytosol extract from weanling rat liver was administrated to the hepatectomized rats[19]. Since then, much effort toward the identification, purification and characterization of this growth-induced substance has been made[2, 3 , 5]. Despite of these, however, little is known about the mechanisms of HSS action on hepatocytes.

It was reported that HSS alone had little effect on the DNA synthesis of the resting hepatocytes as in the primary culture hepatocytes, but in contrast, if combined with EGF, it could amplify the growth response of the cells to EGF both in vitro[20,21] and in vivo[22]. The EGF participation in the regulation of liver proliferation was demonstrated in the down-regulation of EGF receptor following partial hepatectomy[23]. The downregulation was usually associated with the immediate receptor internalization, phosphorylation and production of various second messenger signals as well[17]. In concord with internalization of ligand-receptor complex, the cells commenced DNA synthesis and pro- 
liferated[24, 25]. Although HSS was proven not capable to initiate DNA synthesis in primary culture hepatocytes, it had been confirmed as a gene product of fetal liver cells [26] and reported to stimulate hepatoma cell growth[27]. However, how HSS might act on the hepatocytes has been frequently questioned and so far its mechanism remained unanwered. We speculate that HSS might act as co-stimulator or co-mitogen to promote the growth of hepatocytes. For this reason, we intend to explore the regulatory effect of HSS on hepatocytes, HSS interaction with EGF-receptors and its possible modulation on post-receptor signaling transduction.

In this study, HSS was partially purified and its molecular size was likety to ca. $15 \mathrm{kD}$, which was consistent with the report of Fleig and co-worker[3]. It was also demonstrated in this experiment for the first time that HSS increased EGF specific binding to its receptors and such increase was apparently caused by the enhancement of receptor internalization. Meanwhile, It was also shown in Northern blot that HSS up-regulated EGF-receptor mRNA expression. The consistence of HSS regulation on the EGF-receptor binding and mRNA expression could explain why HSS activated the hepatocytes only when EGF was presented. Although it was clearly shown that the expression of EGFreceptor mRNA was elevated during 24-72 $\mathrm{h}$ either in partially hepatectomized rats or as a result of EGF induction in primary culture of rat hepatocytes[28], however, what is HSS function of HSS during this course and to what extent it might be in volved in were far from understood[29]. The present results indicated that participation of HSS in the regulation of liver cell growth could be executed through its modulation on EGF receptors.

EGF-receptor, as a member of tyrosine protein kinase (TK) receptors, plays a critical role in the hepatic regeneration. The receptors, upon binding to its specific ligands as well as being activated, mediate a cascade of the intracellular signaling and tremendous growth events in the targeted cells[30]. In these experiments, we found that HSS not only promoted synthesis of EGF-receptors, but also stimulated the activities of the newly synthesized receptors. It was implied, on one side, that the increases in EGF receptor synthesis could supply suffcient targets available for EGF or transforming growth factor- $\alpha$ (TGF- $\alpha)$, on other side, the receptor phosphorylation would promote the signaling transduction downstream and enhance the cell growth. It was recently reported that Genestein, a tyrosine kinase inhibitor, prevented HSS-initiated DNA synthesis in the cultured hepatocytes[31], providing a clear implication of HSS modulation to tyrosine kinase.

Although HSS had been recently sequenced[32], but the deduced molecule did not contain the structure necessary for growth signal transduction, nor homology to the other well-known hepatotrophic factor such as insulin, insulin-like growth factor (IGF), TGF- $\alpha$; , even hepatocyte growth factor (HGF). Surprisingly, it did share $50 \%$ amino acid homology to the product of a nuclear gene, ERV1 in yeast[33], which played a critical role in the cell growth regulation[34]. Disruption of this gene caused severe growth defect and irreversible cessation of cell division after 3-4 days[33]. So far, there is no report about mammalian homologue of ERV1, if HSS, as deduced from its gene sequence, 


\section{Regulation of HSS on EGF-receptor}

were mammalian ERV1 and functioned as a nuclear gene for the regulation of cell growth, the EGF-receptor cascade of growth signaling might eventually affect this gene and trigger out the liver regeneration. What is unclear is that why HSS does not affect the resting hepatocytes or stimulate cell DNA synthesis except in the presence of EGF. Our present results pointed out that the mechanism of HSS action should be, at least, related with its modulation to EGF-receptors.

\section{ACKNOWLEDGEMENT}

This work was supported by the National Natural Science Foundation of China (Grant 39600053) and Deutscher Akademischer Austauschdienst (DAAD, German Academic Exchange Service). We thank Mr. Gao Ding-Cheng for his contribution in preparation of the photos and figures and Ms. Rong Yu and Ms. Chen Li for their excellent technical assistances.

\section{REFERENCES}

[1] LaBrecque DR, Pesch LA. Preparation and partial characterization of hepatic regenrative stimulator substance (ss) from rat liver. J Physiol (London) 1975; 248:273-84.

[2] LaBrecque DR, Steele G, Fogerty S, Wilson M, Barton J. Purification and physical-chemical characterization of hepatic stimulator substance. Hepatology 1987; 7:100-6.

[3] Fleig WE, Hoss G. Partial purification of rat hepatic stimulator substance and characterization of its action on hepatoma cells and normal hepatocytes. Hepatology 1989; 9:240-8.

[4] Mei MH, An W, Zhang BH, Shao Q, Gong DZ. Hepatic stimulator substance protects against acute liver failure by CCl4 poisoning in mice. Hepatology 1993; 17:638-44.

[5] Francavilla A, Ove P, Polimeno L, Goetzee M, Makowka L, Rose J, Van Thiel DH, Starzl TE. Extraction and partial purification of a hepatic stimulatory substance in rats, mice and dogs. Cancer Res 1987; 47:5600-5.

[6] Fleig WE, Enderle D, Steudeter S. Regulation of basal and insulin-stimulated glycogen synthesis in cultured hepatocytes. Inverse relationship to glycogen content. J Biol Chem 1987; 262:1155-60.

[7] LaBrecque DR. Hepatic stimulator substance: discovery characteristics and mechanism of action. Dig Dis Sci 1991; 36:669-73.

[8] Liu XJ, An W, Lei TG, Rong Y, Du GG. Regulation of hepatic stimulator substance on the proliferation of human hepatoma cells. Acta Physiol Sinica 1998; 50:543-50.

[9] Dunn WA and Hubbard AL. Receptor-mediated endocytosis of epidermal growth factor by hepatocytes in the perfused rat liver: ligand and receptor dynamics. J Cell Biol 1984; 98:2148-59.

[10] Fleig WE, Hoss G, Noether-Fleig G. Insulin-binding to cultured adult hepatocytes. Effect of bacitracin and chlorquine on the nature of cell-associated radioactivity. Biochem J 1986; 237:99104.

[11] Chomczyniski P and Sacchi N. Single-step method of RNA isolation by acid guanidinium thiocynate-phenol-chloroform extraction. Anal Biochem 1987; 162:156-9.

[12] Laemmli UK. Cleavage of structural proteins during the assembly of the head of bacteriophage T4. Nature 1970; 227:680-5.

[13] Smith PK, Krohn RL, Hermanson GT, Mallia AK, Gartner FH, Provenzano MD, Fujimoto EK, Goeke NM, Olson BJ and Klenk DC. Measurement of protein using bicinchoninic acid. Ana Biochem 1985; 150:76-85.

[14] Mossman TJ. Rapid colorimetric assay for cellular growth and survival: application to proliferation and cytotoxicity assays. J Immunol Methods 1983; 65:55-63.

[15] An W, Schmidt A, Fleig WE. Effects of hepatic stimulator substance on EGF receptor gene 
An W et al.

expression in rat hepatocytes. Chinese J Pathophyiol 1997; 13:540-4 (in Chinese with English abstract).

[16] Carpenter G, Cohen S. Epidermal growth factor. J Biol Chem 1990; 265:7709-12.

[17] Ullrich A, Schleissinger J. Signal transduction by receptor with trysine kiase activity. Cell 1990; 61:203-12.

[18] Michalopoulos GK. Liver regeneration: molecular mechanisms of growth control. FASEB J 1990; 4:176-87.

[19] LaBrecque DR and Bachur NR. Hepatic simulator substance-physicochemical characteristics and specificity. Am J Phyiol 1982; 242:G281-8.

[20] MaGowan JA, Strain AJ, Bucher NLR. DNA synthesis in primary cultures of adult rat hepatocytes in a defined medium: effects of epidermal growth factor, insulin, glucagon and cyclic AMP. J Cell Phyiol 1981; 108:353-63.

[21] Hasegawa K, Watanabe K, Koga M. Induction of mitosis in primary cultures of adult rat hepatocytes under serum-free conditions. Biochem Biophys Res Comm 1982; 104:259-65.

[22] Olsen PS, Boesby S, Kirkgegaard P, et al. Influence of epidermal growth factor on liver regeneration after partial hepatectomy. Hepatology 1988; 8:992-6.

[23] Earp HS and Obeefe EJ. Epidermal growth factor receptor number decreases during rat liver regeneration. J Clin Invest 1981; 67:1580-3.

[24] Eva M, Austin KS, Blaisdell J, et al. Chromatin binding of epidermal growth factor, nerve growth factor and platelet-derived growth factor in cells bearing the appropriate surface receptor. Proc Natl Acad USA 1986; 83:3728-32.

[25] Raper SE, Burwen SJ, Baker ME, et al. Translocation of epidermal growth factor to the hepatocyte nuclei during rat liver regeneration. Gastroenterology 1987; 92:1243-50.

[26] He F, Wu C, Tu Q, Xing G. Human hepatic stimulator substance: a product of gene expression of human fetal liver tissue. Hepatology 1993; 17:225-9.

[27] Yang XM, Hu ZY, Xie L, Wu ZZ, Wu CT, He FC. In vitro stimulation of HTC hepatoma cell grwoth by recombinant human augmenter of liver regeneration. Acta Physiologica Sinica 1997; 49:55761.

[28] Johnson AL, Garfield SH, Merlino GT, et al. Expression of epidermal growth factor receptor proto-oncogene mRNA in regenerating rat liver. Biochem Biophys Res Comm 1988; 150:412-8.

[29] Michalopoulos GK, DeFrance MC. Liver regeneration: Molecular mechanisms of growth control. Science 1997; 276:60-6.

[30] Carpenter G, Cohen S. Epidermal growth factor. J Biol Chem 1990; 265:7709-12.

[31] Diehl AM, Rai RM. Regulation of signal transduction during liver regeneration. FASEB J 1996; 10:215-27.

[32] Hagiya M, Francavilla A, Polimeno L, Ihara I, Sakai H, Seki T, Shimonishi M, Porter KA, Starzl TE. Cloning and sequence analysis of the rat augmenter of liver regeneration (ALR) gene: expression of biologically active recombinant ALR and demonstration of tissue distribution. Proc Natl Acta Sci USA 1994; 91:8142-6.

[33] Lisowsky T. Dual function of a new nuclear gene for oxidative phosphorylation and vegetative growth in yeast. Mol Gen Genet 1992; 232:58-64.

[34] Grivell LA. Nucleo-mitochondrial interaction in yeast mitochondrial biogenesis. Eur J Biochem 1994; 182:477-93. 